\title{
Does access to credit reduce SMEs' tax avoidance? Evidence from a regression discontinuity design
}

\author{
Xiaowei Kong ${ }^{1}$, Deng-Kui $\mathrm{Si}^{2}$, Haiyang $\mathrm{Li}^{3^{*}}$ and Dongmin Kong ${ }^{4}$ (1)
}

\section{*Correspondence:}

lihaiyang@stu.zuel.edu.cn

${ }^{3}$ School of Finance,

Zhongnan University

of Economics and Law,

Wuhan, China

Full list of author information

is available at the end of the

article

\begin{abstract}
This study investigates the effect of targeted reserve requirement ratio cuts (TRRRCs) on tax avoidance among small and micro enterprises (SMEs) with operating revenues below specific cutoffs in China. Using a regression discontinuity design, we causally show that, by increasing loan availability, TRRRCs significantly alleviate the financial constraints and cash dependence of SMEs and consequently reduce tax avoidance. This is especially the case among firms with lower market power and higher entertainment and travel costs. Our findings provide evidence for the real effect of TRRRCs on corporate tax avoidance and show the inclusive effect of TRRRCs on SMEs. In doing so, we indirectly reveal a rent-seeking channel underlying bank lending, thus offering clear policy implications for regulators.
\end{abstract}

Keywords: Access to finance, Small and micro enterprises (SMEs), Tax avoidance, Targeted reserve requirement ratio cuts (TRRRCs)

JEL Classification: E52, G32, H25

\section{Introduction}

Financial constraints reduce the productivity of small and micro enterprises (SMEs) (Cao and Leung 2019) and hinder their growth (Beck and Demirguc-Kunt 2006). As financial technology is widely used in the domain of financial risk analysis (e.g., Kou et al. 2014), and massive payment and transaction data help improve bankruptcy prediction models for SMEs (e.g., Kou et al. 2020), it is increasingly difficult for SMEs with potential business risks to finance through formal institutions (e.g., bank loans and the capital market). To alleviate the financial constraints of SMEs, targeted credit policies can be effective for allocating more funds to the small business sector (e.g., Bach 2014; Banerjee and Duflo 2014; Krishnan et al. 2015; Lin et al. 2020). At the same time, financial constraints lead firms to increase internally generated funds via tax avoidance (Law and Mills 2015; Edwards et al. 2016; Luo et al. 2020). Yet, little is known about the relationship between access to finance caused by targeted credit policies and firms' tax avoidance. To support the development of SMEs, the People's Bank of China (PBOC) has begun to implement a structural monetary policy of targeted reserve requirement author(s) and the source, provide a link to the Creative Commons licence, and indicate if changes were made. The images or other third party material in this article are included in the article's Creative Commons licence, unless indicated otherwise in a credit line to the material. If material is not included in the article's Creative Commons licence and your intended use is not permitted by statutory regulation or exceeds the permitted use, you will need to obtain permission directly from the copyright holder. To view a copy of this licence, visit http:// creativecommons.org/licenses/by/4.0/. 
ratio cuts (TRRRCs). Using TRRRCs as a natural experiment, we investigate the effect of easier access to finance on corporate tax avoidance, which is a very important financing channel, especially for SMEs in China. ${ }^{1}$

Theoretically, there is a substitution effect between tax avoidance and debt financing (DeAngelo and Masulis 1980). First, high external financing costs cause financially constrained firms to rely substantially on internal financing (e.g., tax avoidance) to raise funds. The "cash flow effect" hypothesis holds that companies can save internal cash through reasonable tax avoidance (Dyreng et al. 2008; Law and Mills 2015; Edwards et al. 2016; Goh et al. 2016; Jia et al. 2020), thus reducing reliance on external financing, such as bank credit. Additionally, the non-debt tax shield formed through firms' tax avoidance can replace the debt tax shield, leading to a decline in corporate debt financing needs.

Defining financial constraints as rising external financing costs, or increasing difficulty with obtaining external financing, Edwards et al. (2016) find that financing-constrained firms have more aggressive tax-avoidance behaviors. Firms facing financial constraints have limited financing channels, and tax expenses lead to a large amount of cash outflow. With an urgent demand for funds, financing-constrained firms can ease cash-flow pressure through reasonable tax avoidance. Therefore, such firms are willing to bear the risks brought by tax avoidance. In addition, the declining availability of bank loans changes the equilibrium state of corporate tax avoidance, and the marginal benefit of tax avoidance becomes greater than the marginal cost; firms will therefore engage in tax avoidance (Chen et al. 2010; Lanis et al. 2020). In particular, the cash-holding value of financing-constrained firms is higher than that of unconstrained firms (Faulkender and Wang 2006; Denis and Sibilkov 2009; Xiong et al. 2020), and the marginal cash benefits of tax avoidance are higher for financing-constrained firms (Goh et al. 2016). Thus, better access to bank loans improves corporate financing conditions, thereby reducing the marginal benefits of tax avoidance for financing-constrained firms; as a result, tax-avoidance activities may decline.

In addition, during a period of loose monetary policy, credit supply is relatively abundant, and it is thus easier to obtain external financing. In that case, financing costs are lower, and the marginal benefit of tax avoidance is smaller than it is during a period of monetary tightening (Faulkender and Wang 2006). Firms are therefore more willing to use debt financing. At the same time, tax avoidance increases the risk of corporate litigation, increases the cost for companies to obtain bank loans, affects corporate reputation (Hasan et al. 2014), and negatively affects corporate value. Given the likelihood of being detected by tax inspectors, firms will engage in less risky tax-avoidance activities.

However, the empirical evidence in this area is inconsistent (Francis et al. 2017). Further, the investigation of the relationship between tax avoidance and debt financing faces serious endogeneity problems (Graham and Tucker 2006).

TRRRC is essentially a statutory deposit reserve system. In Chinese monetary policy, required reserves have been the main policy instruments used for macroeconomic

\footnotetext{
${ }^{1}$ The "Survey Report on the Financing Status of Small and Micro Enterprises in Midwest China," released by the National Development Research Institute of Peking University and Alibaba Group in 2012, showed that 53.94\% of SMEs were affected by insufficient funds, and $60.81 \%$ believed the burden of taxes and fees affected business operations, and only through reasonable tax avoidance could they continue to survive.
} 
stabilization. For example, the PBOC has adjusted the required reserve ratio (RRR) more than 40 times since 2006. Chang et al. (2019) argue that RRR adjustments have reallocated credit resources under China's existing financial system.

Compared to traditional RRR cuts, TRRRCs are a credit-easing monetary policy for targeted sectors, including SMEs. This policy does not cut the RRR of all financial institutions but only reduces the RRR for financial institutions, such as commercial banks, whose SME loan balances reach a sufficient percentage. TRRRCs affect SMEs' loan availability in two ways. On the one hand, RRR cuts mean banks can deposit fewer reserves in the PBOC, which is beneficial for maximizing profit, and more banks are motivated to provide more credit to SMEs for TRRRC eligibility. On the other hand, under the supervision of the PBOC, eligible banks are required to release more funds for SMEs.

Based on the natural experiment of implementing TRRRCs, which are inclusive financial policies in China intended to ease SMEs' financing difficulties by increasing loan availability, and referring to the demarcation criteria for SMEs in China, we use a regression discontinuity design (RDD) to explore causality between access to finance and corporate tax avoidance.

Based on the clear demarcation criteria for SMEs, we define the reference variable (running variable) as the distance of the logarithm of the operating revenue threshold from the logarithm of the firm's operating revenue; hence, the cutoff point is equal to zero. By comparing the tax avoidance of firms near the cutoff point, we can identify the effect of TRRRCs on tax avoidance among SMEs. We mainly find that TRRRC implementation leads to a reduction in tax avoidance among SMEs in China. After TRRRCs increase in loan availability for SMEs, their tax avoidance is reduced by about $30 \%$. Further, our underlying mechanism examinations show that by increasing loan availability for SMEs, TRRRCs ease their financial constraints and dependence on cash, consequently reducing their tax avoidance. Various robustness tests suggest that the results are consistent. Lastly, cross-sectional tests based on firms' market power and entertainment and travel costs (ETCs) provide evidence for the inclusive effect of TRRRCs while supporting the view that bribery greases the wheels of bank lending (Chen et al. 2013). As a result of the scarcity of credit resources provided by TRRRCs to SMEs, rent-seeking behaviors have been spawned. ETCs are important expenditures for rent-seeking enterprises and are conducive to forming political connections that will facilitate access to various resources (e.g., Hou and $\mathrm{Li} \mathrm{2019;} \mathrm{Hu}$ and $\mathrm{Xu}$ 2019). Such enterprises are also more likely to avoid taxation. This may amplify the negative effect on tax avoidance of the increased loan availability caused by TRRRCs.

In summary, our main contributions are as follows. First, utilizing the exogenous shock of TRRRCs on precisely identified SMEs in China, we employ RDD to study the causal effect of access to finance on corporate tax avoidance. The most closely related study is Francis et al. (2017), who find no evidence for the substitutive relation between bank credit and corporate tax avoidance, even for firms with higher financial constraints. Compared to Francis et al. (2017), our analysis focuses on SMEs' tax avoidance based on a more exogenous and cleaner shock to loan availability. TRRRCs are a "targeted ease" monetary policy intended to provide more funds only for SMEs; thus, there is no effect on tax avoidance among non-SMEs. However, the banking deregulation policy used in Francis et al. (2017) may have the opposite effect on firms with heterogeneous 
characteristics. For example, large firms obtain more bank loans whereas the amount of bank loans for SMEs is not affected (Rice and Strahan 2010), which could distort the average effect of banking deregulation on tax avoidance.

Second, our research is related to the literature on financial constraints and tax avoidance. Cai et al. (2018) use China's Corporate Tax Collection Reform to study the effect of taxes on firm innovation. They find that explicitly lowering the tax rate is conducive to firm development, especially for financially constrained and tax-aggressive firms, suggesting that financial constraints and tax burdens hinder firm innovation. In addition, many empirical studies show that companies facing financial constraints will hold cash through active tax avoidance to achieve internal financing (Law and Mills 2015; Richardson et al. 2015; Edwards et al. 2016). However, there is little research on whether improving the financing environment will inhibit corporate tax avoidance. Logically, if the external financing environment is improved (e.g., during a period of loose monetary policy), external financial constraints are weakened, and companies' dependence on cash can decrease. According to the "cash flow effect" of corporate tax avoidance, tax-avoidance motivation will be reduced. We fill this gap by investigating whether tax avoidance is reduced after TRRRCs ease SMEs' financial constraints and dependence on cash.

Moreover, this study adds to the literature investigating the effect of unconventional monetary policy on the real economy. Specifically, we evaluate the effect of China's unconventional deposit reserve system on SMEs' financing by way of tax avoidance. The TRRRC policy lowers the deposit reserve ratio of banks with sufficient loans for SMEs; this is the essential difference between TRRRC and the traditional RRR (reserve requirement ratio) cut policy. Additionally, the TRRRC policy encourages banks to provide more credit support to SMEs. Using the financial information of Chinese companies traded on the Small and Medium Enterprise Board and the ChiNext Board of the Shenzhen Stock Exchange, as well as a fixed-effects model, Lin et al. (2020) show that TRRRCs help reduce the financing constraints of small businesses. Our work differs in several ways. First, we study how access to finance affects firms' tax avoidance considering that TRRRCs improve loan availability for SMEs. Second, considering the tradeoff between financial information availability and firm size, our sample covers all firms listed on the National Equities Exchange and Quotations, which is suitable for studying the financing problems of SMEs (Wu and $\mathrm{Xu}$ 2020). In addition, we use the RDD method, which is currently widely used in corporate finance research to identify causality (e.g., Chava and Roberts 2008; Bradley et al. 2016; Cai et al. 2018; Chemmanur and Tian 2018; Zhang 2019).

Cash flow, which indicates the status of a firm's liquid assets, is important for reinvesting in the business, returning money to shareholders, paying expenses, and providing a buffer against future financial challenges. In addition, cash flow plays an important role in the R\&D of young, innovative SMEs (Brown et al. 2009). According to our results, on the one hand, the policy increases bank loan availability for SMEs, enabling them to get more cash flow, which could further improve firm labor or capital input for production increases. The connections associated with bank loans also help firms build relationships with banks. This alleviates information asymmetry between banks and firms and helps banks to play a monitoring role in firms' activities. On the other hand, since the policy reduces tax avoidance, SMEs remit more taxes, which may lead to less cash flow and 
investment. Therefore, the overall effect of TRRRCs on firms' cash flow and profitability remains ambiguous, and it is ultimately an empirical issue.

The rest of this paper is organized as follows. "Institutional background of TRRRCs" section describes the background of TRRRCs in China. "Data, variables, and method" section describes the data and outlines the empirical strategy. The empirical analysis of the main findings and the underlying mechanisms are presented in "Empirical results and analysis" section. "Conclusions" section concludes the paper.

\section{Institutional background of TRRRCs}

The Chinese economy, which is still in a period of transition, faces various opportunities and challenges. Steady growth and high-quality development require the constant injection of new dynamics. SMEs are an important part of the national economy and the cradle of innovation. They play an important role in promoting economic growth, increasing employment, and activating market vitality. However, financial constraints have been a stumbling block to the development of SMEs in China for a long time. Due to asymmetrical and inaccurate information in the financial market, it can be difficult and expensive for SMEs to obtain funding. Compared to developed countries, China's capital market has developed slowly, and commercial banks have always dominated the financial system. This has led to bank credit becoming the main form of corporate financing in China (Allen et al. 2005). Meanwhile, credit discrimination exists among banks, and a large amount of bank credit flows into state-owned enterprises and listed companies, which makes it more difficult for SMEs to obtain bank credit given their higher operating risks and lower credit. In addition, as interest rate liberalization progresses, although bank liquidity creation increases (Zhang and Deng 2020), it is more difficult for credit resources to flow into SMEs that are weak in terms of market competition.

To alleviate financing difficulties and support SME development, PBOC began implementing TRRRCs in June $2014 .^{2}$ TRRRCs cut the reserve requirement ratio (RRR) for eligible banks and encourage those banks to allocate more funds to areas the real economy needs to support. The PBOC also requires financial institutions to earnestly follow the direction of credit policies and provide the released funds to key national economic areas, such as "agriculture, rural areas, [and] farmers," as well as SMEs, promoting the optimization of the credit structure. The PBOC has also strengthened the inspection and supervision of the implementation of financial institutions, evaluated the effect of policies, and maintained a positive incentive effect.

In fact, there are clear standards for SMEs in China. The "Regulations on the Standards for Classification of Small and Medium-Sized Enterprises" (henceforth, Regulations) stipulate operating revenue thresholds in various industries as the classification criteria and define firms with operating revenues below the threshold as SMEs. ${ }^{3}$ For example, the Regulations stipulate that for heavy industry, firms with an operating income below 20 million RMB are SMEs. By checking whether the operating income is less than 20

\footnotetext{
${ }^{2}$ The RRR of banks engaged in proportionate lending to agriculture and small firms is cut by $0.5 \%$.

${ }^{3}$ China's Ministry of Industry and Information Technology and four other departments jointly issued the "Regulations on the Standards for Classification of Small and Medium-sized Enterprises" in 2011.
} 
Table 1 Cutoff values of SMEs in China in different industries

\begin{tabular}{llll}
\hline Industry & $\begin{array}{l}\text { Operating } \\
\text { revenue (RMB) } \\
\text { (million) }\end{array}$ & Industry & $\begin{array}{l}\text { Operating } \\
\text { revenue (RMB) } \\
\text { (million) }\end{array}$ \\
\hline $\begin{array}{llll}\text { Agriculture, forestry, livestock } \\
\text { farming, and fishery industry }\end{array}$ & $<5$ & Accommodation industry & $<20$ \\
Heavy industry & $<20$ & Restaurant and catering industry & $<20$ \\
Construction industry & $<60$ & Information transmission industry & $<10$ \\
Wholesale trade industry & $<50$ & Software and IT service industry & $<10$ \\
Retail industry & $<5$ & Real estate development industry & $<10$ \\
Transportation industry & $<30$ & Property management industry & $<10$ \\
Warehousing industry & $<10$ & Tenancy and business services industry & - \\
Postal industry & $<20$ & Other unlisted industries & -
\end{tabular}

Firms in "Tenancy and Business Services Industry" and "Other Unlisted Industries" are classified by whether the number of employees is less than 100 , other than operating revenue

million, we can identify SMEs in heavy industry. Table 1 shows the operating income standards for SMEs in all industries.

\section{Data, variables, and method}

Data and variables

Financial data for SMEs such as individual merchants are very scarce. However, the firms listed on the National Equities Exchange and Quotations (NEEQ) include most SMEs with sound financial information disclosure. Thus, this study uses a financial dataset for firms listed on the NEEQ. The data come from the China Securities Market and Accounting Research (CSMAR) database, which is widely used in China-related studies.

RDD requires a running variable, which, in our study, is intended to specify which firms are shocked by TRRRCs or which ones are SMEs mentioned by the PBOC. The treatment effect is assigned to firms whose running variable is above a known, exact cutoff. Based on the abovementioned regulation shock, we define the running variable as the distance of a firm's operating revenue from the corresponding industry-specific operating revenue threshold. In particular, the running variable SALEDIFF is defined as follows:

$$
\text { SALEDIFF }=\ln (\widetilde{\mathrm{SALE}})-\ln (\mathrm{SALE})
$$

where $\ln (\widetilde{\text { SALE }})$ is the natural logarithm of the corresponding industry-specific operating revenue threshold, and $\ln$ (SALE) is the natural logarithm of a firm's operating revenue. A positive SALEDIFF indicates an SME.

Although the lower RRR of TRRRCs is only for banks providing loans to SMEs, various factors may be considered when banks lend; for example, firms with SALEDIFF $>0$ could not be assigned treatment. Obtaining bank loans more easily is the most direct effect of TRRRCs on SMEs. We determine that a firm has been assigned treatment by its loans having increased after TRRRCs; then, we use fuzzy RDD to assess the effect of TRRRCs on tax avoidance for SMEs. For this purpose, we use the difference between short-term debt and trade credit to approximate the level of loans (Berger and Udell 2006). Then, we define $T R C=1$ if the firm's loan increases more than the median value, 
indicating that the firm is affected by the TRRRC. Following Angrist and Lavy (1999) and Van der Klaauw (2002), we conduct fuzzy RDD in an instrument variable (IV) framework. We define $S M E$, which is equal to unit when $S A L E D I F F>0$, as an instrument for TRC. Since we cannot directly observe the treatment status of a firm, referring to Pan and Singhal (2019), a sharp RDD is also conducted for robustness. ${ }^{4}$

We use book-tax differences $(B T D)$ as the outcome variable to measure the firm's tax avoidance. $B T D$ is calculated as the difference between pretax accounting profit and taxable income, scaled by total asset. A higher BTD can indicate more tax avoidance (Desai and Dharmapala 2006). Chan et al. (2010) found that the BTD of listed Chinese firms was significantly positively related to tax audit adjustments issued by the tax authorities. The taxation department in China uses BTD as an important indicator for judging the existence of tax avoidance among enterprises. Book-tax differences can arise from tax avoidance or earnings management. Therefore, to eliminate the effect of earnings management, following Desai and Dharmapala (2006), we use book-tax differences that cannot be explained by accrued profits to measure corporate tax avoidance as another measure of tax avoidance, which is denoted DDBTD.

We also use the following covariates that reflect characteristics of the enterprise: the ratio of cash flow from operating activities to total assets (CFO), the ratio of liabilities to total assets (LEVERAGE), the ratio of fixed assets to total assets (FIXED), and the ratio of investment expenditure to total assets (INVEST).

TRRRCs for SMEs were first launched on June 16, 2014, and the National Bureau of Statistics of China changed the standards for SME classification at the end of 2017; thus, our sample period is 2014-2017. We exclude financial firms and firms delisted before 2018. We also require no missing values for the dependent variable, the running variable, and all covariates. All continuous variables are winsorized at the first and 99th percentiles. Our final sample consists of 10,187 firm-year observations, and $14.7 \%$ of the observations come from SMEs.

\section{Descriptive analysis}

Table 2 reports the summary statistics of the main variables. Panel A presents summary statistics for the full sample. The outcome variable $B T D$ has an average of -0.022 and a median of -0.004 , suggesting that tax-avoidance activities exist in $50 \%$ of the sample firms.

Panel B and panel C separately present the summary statistics for the SMEs subsample and the non-SMEs subsample, respectively. The average BTD values of the SME and non-SME subsamples are -0.068 and -0.014 , respectively, suggesting that, on average, the tax avoidance of SMEs is lower than that of non-SMEs after TRRRC implementation. For covariables, the SMEs and non-SMEs in the sample have small differences in terms of CFO, LEVERAGE, FIXED, and INVEST.

\footnotetext{
${ }^{4}$ Meng (2013) evaluated China's poverty alleviation program using RDD in an IV framework. The reduced-form equation in Meng (2013) is similar to our sharp RDD equation.
} 
Table 2 Summary statistics

\begin{tabular}{|c|c|c|c|c|c|c|}
\hline & Observations & Mean & SD & 25th & Median & 75th \\
\hline \multicolumn{7}{|c|}{ Panel A: Full sample } \\
\hline BTD & 10,187 & -0.022 & 0.092 & -0.029 & -0.004 & 0.015 \\
\hline SALEDIFF & 10,187 & -1.309 & 1.372 & -2.145 & -1.392 & -0.592 \\
\hline CFO & 10,187 & 0.026 & 0.150 & -0.049 & 0.032 & 0.107 \\
\hline LEVERAGE & 10,187 & 0.395 & 0.199 & 0.237 & 0.390 & 0.539 \\
\hline INVEST & 10,187 & 0.058 & 0.074 & 0.008 & 0.029 & 0.077 \\
\hline FIXED & 10,187 & 0.166 & 0.154 & 0.033 & 0.121 & 0.262 \\
\hline \multicolumn{7}{|c|}{ Panel B: Sample of SMEs } \\
\hline BTD & 1493 & -0.068 & 0.145 & -0.092 & -0.019 & 0.007 \\
\hline SALEDIFF & 1493 & 1.016 & 0.834 & 0.412 & 0.834 & 1.398 \\
\hline CFO & 1493 & -0.021 & 0.197 & -0.130 & -0.009 & 0.101 \\
\hline LEVERAGE & 1493 & 0.314 & 0.203 & 0.142 & 0.283 & 0.451 \\
\hline INVEST & 1493 & 0.066 & 0.092 & 0.006 & 0.026 & 0.086 \\
\hline FIXED & 1493 & 0.148 & 0.164 & 0.024 & 0.073 & 0.230 \\
\hline \multicolumn{7}{|c|}{ Panel C: Sample of non-SMEs } \\
\hline BTD & 8694 & -0.014 & 0.077 & -0.024 & -0.003 & 0.016 \\
\hline SALEDIFF & 8694 & -1.708 & 0.999 & -2.283 & -1.612 & -0.973 \\
\hline CFO & 8694 & 0.034 & 0.139 & -0.038 & 0.037 & 0.108 \\
\hline LEVERAGE & 8694 & 0.409 & 0.195 & 0.256 & 0.405 & 0.550 \\
\hline INVEST & 8694 & 0.056 & 0.070 & 0.009 & 0.029 & 0.076 \\
\hline FIXED & 8694 & 0.170 & 0.152 & 0.036 & 0.130 & 0.266 \\
\hline
\end{tabular}

This table reports descriptive statistics of key variables. Panel A to Panel C present statistics of the full sample, the subsample of SMEs and the subsample of non-SMEs. All data come from CSMAR

\section{Method}

\section{RD design}

As "targeted ease" monetary tools, TRRRCs cut the RRR of eligible banks to help increase SMEs' access to financing. The operating revenue-based classification standards for SMEs in China create a discrete relationship between the distance of a firm's operating revenue from the corresponding operating revenue threshold and the firm's likelihood of being treated. These conditions provide an opportunity for using an RDD to evaluate the effect of TRRRCs on SMEs' tax avoidance by increasing SMEs' loan availability (Hahn et al. 2001).

The liquidity shock caused by TRRRC implementation should be identifiable given the requirement that only firms with annual sales below the corresponding sales threshold in the industry can be SMEs. Firms located just below the threshold should show no significant differences from firms located just above the sales threshold. Consequently, any difference in outcomes generated by TRRRCs between these two groups of firms should be attributed to SME eligibility. This identification strategy is similar to Bach (2014), who exploits a French targeted credit program to examine whether public financing aid reduces small businesses' credit constraints.

Following Angrist and Lavy (1999), Van der Klaauw (2002), Imbens and Lemieux (2008), Lee and Lemieux (2010), and Meng (2013), we use nonparametric local linear/ 
Table 3 The effect of TRRRCs on access to finance

\begin{tabular}{|c|c|c|c|c|c|c|}
\hline & \multicolumn{2}{|c|}{$75 \%$ CCTF } & \multicolumn{2}{|l|}{ CCTF } & \multicolumn{2}{|c|}{$150 \%$ CCTF } \\
\hline & (1) & $(2)$ & (3) & (4) & (5) & (6) \\
\hline \multirow[t]{2}{*}{ SME } & $0.154^{* *}$ & $0.143^{* *}$ & $0.159^{* * *}$ & $0.204^{* * *}$ & $0.176^{* * *}$ & $0.186^{* * *}$ \\
\hline & $(0.063)$ & $(0.072)$ & $(0.057)$ & $(0.058)$ & $(0.043)$ & $(0.049)$ \\
\hline Polynomial & Linear & Quadratic & Linear & Quadratic & Linear & Quadratic \\
\hline Covariates & No & Yes & Yes & No & No & Yes \\
\hline Sample size & 1532 & 2921 & 1844 & 4843 & 3718 & 6,686 \\
\hline
\end{tabular}

$S M E$ is an indicator variable that is equal to one if the firm's operation revenue was below the threshold of operation revenue. The outcome variable is TRC, which is equal to one if a firm obtains a better access to finance. The discontinuity estimates are based on local linear/quadratic regressions. Standard errors are in the parentheses. ${ }^{*},{ }^{* *}$, and ${ }^{* * *}$ represent statistical significance level at the $1 \%, 5 \%$ and $10 \%$ levels, respectively

quadratic regression to perform tests. The local linear regression model for fuzzy RDD is as follows ${ }^{5}$ :

$$
\begin{aligned}
& \operatorname{TRC}_{i, t}=\alpha_{0}+\alpha_{1} \text { SME }_{i, t}+\alpha_{2} \text { SALEDIFF }_{i, t}+\alpha_{3} \text { SME }_{i, t} \times \operatorname{SALEDIFF}_{i, t}+\xi_{i, t}, \\
& \text { BTD }_{i, t}=\beta_{0}+\beta_{1} \text { TRC }_{i, t-1}+\beta_{2} \text { SALEDIFF }_{i, t-1}+\beta_{3} \text { SME }_{i, t-1} \times \operatorname{SALEDIFF~}_{i, t-1}+\varepsilon_{i, t} .
\end{aligned}
$$

We use the 2SLS method to estimate the model. Equation (2) is the first-stage regression model, where TRC is instrumented by SME. TRC indicates whether a firm is affected by TRRRCs. If TRRRC indeed affects a firm's financial condition, then the most direct effect may be that the firm has easier access to bank loans. Equation (2) is used to determine whether the effect of TRRRCs on SMEs' access to bank loans is statistically significant.

Table 3 reports estimated results, which suggest that the distance of the operating revenue from the threshold has strong predictive power for increased loan availability after TRRRCs. Based on CCFT bandwidth, columns (3) and (4) show a 0.16 and 0.20 higher probability, respectively, of increased loan availability among SMEs, compared to non-SMEs. These results are not sensitive to $75 \%$ and $150 \%$ of the CCFT bandwidth, as shown in columns (1) and (2) and columns (5) and (6). For columns (1)-(6), we alternately use linear and quadratic polynomial regression models to cross-check the robustness of the results.

The interaction term $S M E \times S A L E D I F F$ allows for different regression parameters on either side of the cutoff. $\alpha_{1}$ captures the probability of SMEs' loan availability being increased by TRRRCs, and $\beta_{1}$ captures the effect of access to finance on SMEs' tax avoidance. Hence, after TRRRCs, if SMEs' access to financing is increased, the change in tax avoidance is quantified by $\alpha_{1} \beta_{1}$.

Our choice of bandwidth relies on the MSE-optimal method proposed by Calonico et al. (2019) (henceforth, CCTF), which is an upgraded version of the optimal bandwidth selectors presented in Imbens and Kalyanaraman (2012) and Calonico et al. (2014). The

\footnotetext{
$\overline{5}$ Our sharp RDD equation is $B D_{i, t}=\beta_{0}+\beta_{1} S_{M E_{i, t-1}}+\beta_{2}$ SALEDIFF $_{i, t-1}+\beta_{3}$ SME $_{i, t-1} \times$ SALEDIFF $_{i, t-1}+\varepsilon_{i, t}$, which is similar to the reduced-form equation in Meng (2013).
} 


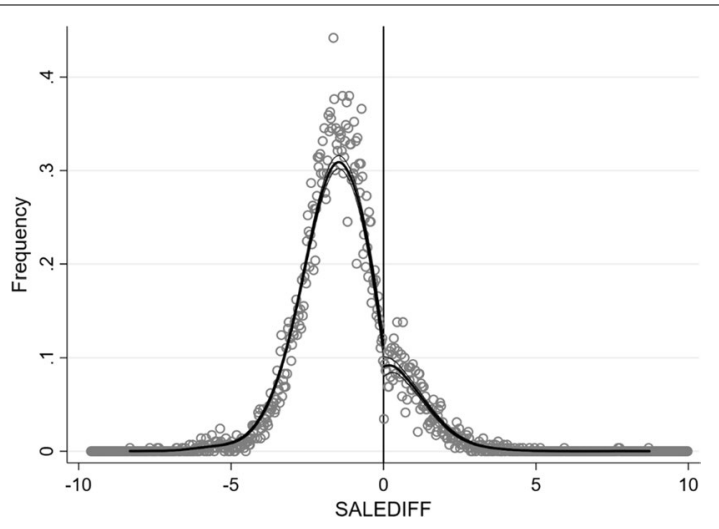

Fig. 1 Density distribution of differences between operation revenue and operation revenue threshold. Notes Based on McCrary (2008), this figure shows the density of the running variable SLEDIFF. The solid line represents the fitted density function of the running variable with a $95 \%$ confidence interval. The discontinuity estimate of the density of the running variable is statistically insignificant with the $0.336 p$ value

rectangular kernel is used as the kernel weighting function. For robustness, we also use 0.75 times and 1.5 times the optimal bandwidth to perform baseline analysis.

\section{Identification assumptions}

Before performing the analysis, we need to check two important assumptions for the validity of the RDD. First, if firms anticipate TRRRCs, to obtain the benefits provided by the policy, they may conduct revenue manipulation, which will cause selection bias. We check the manipulation of the running variable SALEDIFF around the cutoff based on the method proposed by McCrary (2008). Figure 1 plots the estimated density function with a 95\% confidence interval of the running variable, intuitively showing that there is no jump at the cutoff. More formally, the discontinuity estimate of the density of the running variable is statistically insignificant with a $0.336 p$ value. Thus, we cannot reject the null hypothesis of no discontinuity in the density of SALEDIFF at the cutoff.

To further exclude the possibility that firms may manipulate sales to obtain access to bank loans, we control for the one-period lagged $S A L E$ variable in all regressions and examine the effect of bank loan availability on tax avoidance in the first year of TRRRCs for robustness.

Second, we examine whether firms around the cutoff have similar characteristics. In Fig. 2, we plot the average covariates of equally spaced bins with local linear fitted curves on either side of the cutoff. There are clear overlaps between the $95 \%$ confidence intervals at the cutoffs for all covariates, indicating the similarity of firms' characteristics at the cutoff.

Table 4 presents the formal continuity tests for covariates. For each covariate, the coefficient of $S M E$ is statistically insignificant, which implies the continuity of the firm's characteristics at the cutoff.

\section{Empirical results and analysis}

\section{Baseline results}

We implement the RDD strategy to show the causal effect of access to finance on firms' tax avoidance. Before presenting the formal regression results, we use graphical analysis to provide evidence of TRRRCs' effect on firms' tax avoidance. Figure 3 separately 

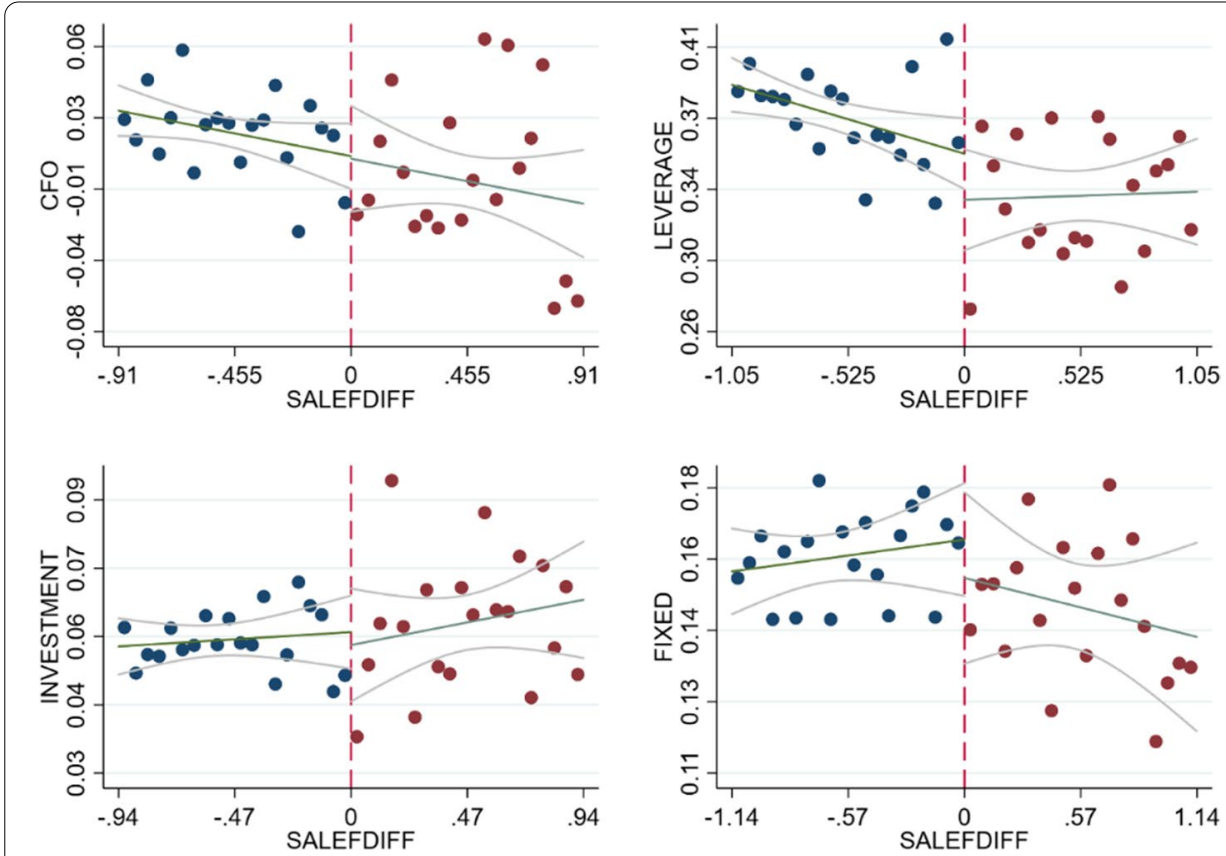

Fig. 2 Similarity of firms' characteristics around the cutoff. Notes Each dot represents the average value of attribute variable for firms within one of 20 equally spaced bins. The fitted lines are based on local linear regressions with a $95 \%$ confidence interval around the predicted value

Table 4 Continuity of characteristics at the cutoff

\begin{tabular}{|c|c|c|c|c|c|c|c|c|}
\hline & \multicolumn{2}{|l|}{ CFO } & \multicolumn{2}{|c|}{ LEVERAGE } & \multicolumn{2}{|c|}{ INVESTMENT } & \multicolumn{2}{|l|}{ FIXED } \\
\hline & (1) & (2) & (3) & (4) & (5) & (6) & (7) & (8) \\
\hline SME & $\begin{array}{l}-0.006 \\
(0.015)\end{array}$ & $\begin{array}{l}-0.007 \\
(0.020)\end{array}$ & $\begin{array}{l}-0.030 \\
(0.019)\end{array}$ & $\begin{array}{l}-0.029 \\
(0.021)\end{array}$ & $\begin{array}{l}-0.000 \\
(0.006)\end{array}$ & $\begin{array}{l}-0.003 \\
(0.010)\end{array}$ & $\begin{array}{l}-0.019 \\
(0.015)\end{array}$ & $\begin{array}{l}-0.022 \\
(0.019)\end{array}$ \\
\hline Polynomial & Linear & Quadratic & Linear & Quadratic & Linear & Quadratic & Linear & Quadratic \\
\hline Sample size & 3575 & 3149 & 2535 & 4414 & 3078 & 4171 & 2673 & 4246 \\
\hline
\end{tabular}

SME is an indicator variable that is equal to one if the firm's operation revenue was below the threshold of operation revenue. The discontinuity estimates are based on local linear/quadratic regressions. Standard errors are in the parentheses

plots the probability of increased loan availability shocked by TRRRCs and tax avoidance against the running variable SALEDIFF on the left and right sides. Linear functions are used to predict values in the top two graph curves on either side of the cutoff, and quadratic functions are used in the bottom two graphs.

The left two graphs in Fig. 3 show that there are significant discontinuities in the probability of increased loan availability at the cutoff. Intuitively, the probability of increased loan availability is approximately 0.16 higher among SMEs after TRRRCs. The right two graphs in Fig. 3 show discernible discontinuities in the outcome variable at the threshold, indicating that the tax avoidance of firms that are barely SMEs is roughly 0.04 lower than that of firms that are barely non-SMEs.

Table 5 reports the baseline discontinuity estimates. The IV estimates reported in panel A in Table 5 show a significant negative effect of access to finance on tax avoidance after TRRRCs. Based on 75\%, 100\%, and 150\% of the CCFT bandwidth, the linear and 

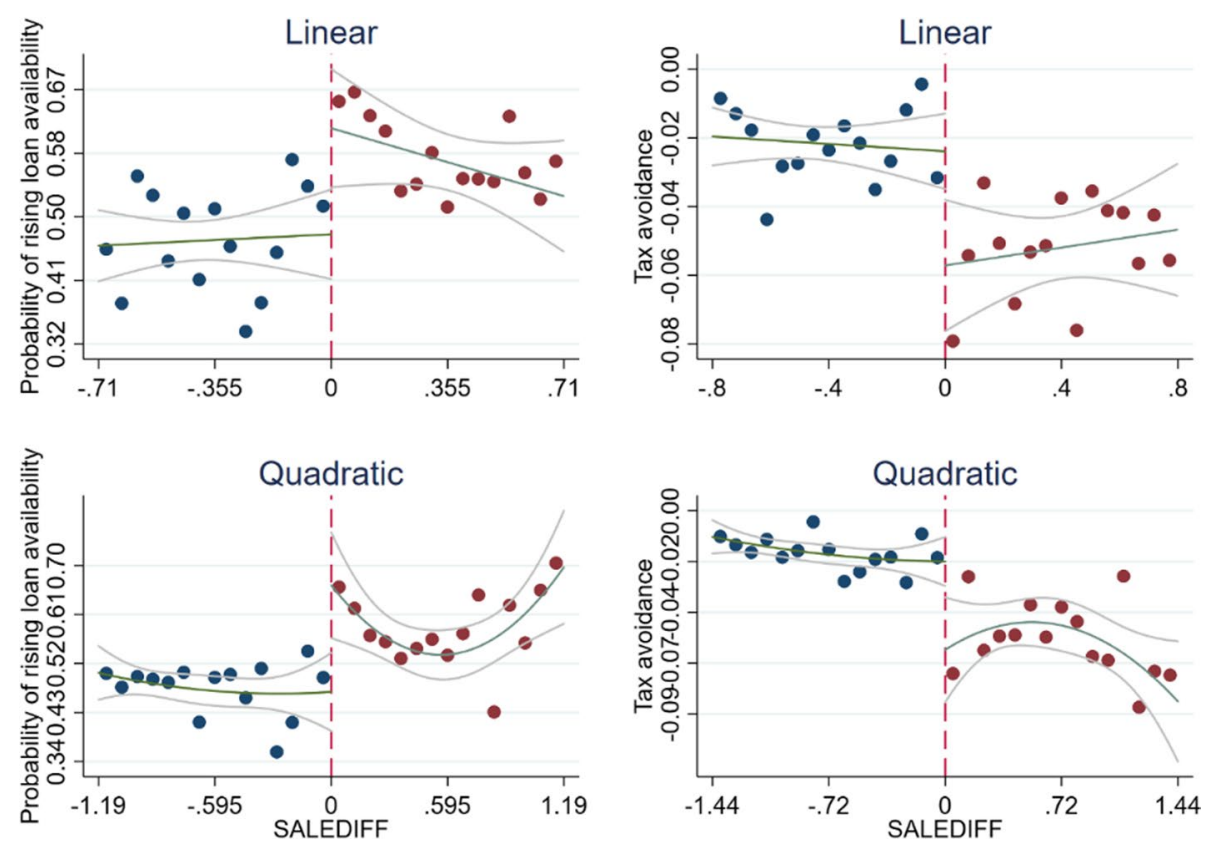

Fig. 3 Discontinuity in probability of loan rise and tax avoidance at the cutoff. Notes Panels refer to the average probability of rising loan availability and tax avoidance (from left to right). Each dot represents the average value within a 20 equally spaced bin. The fitted curves are based on linear regressions (top graphs) and quadratic regressions (bottom graphs), separately, with a 95\% confidence interval around the predicted value

quadratic polynomial regression estimates imply that TRRRCs reduced SMEs' tax avoidance by roughly $26 \%$ while increasing their access to finance. Covariates are alternately added in the regression models to ensure the robustness of the results.

The estimates of the sharp RDD in panel B of Table 5 suggest that SME eligibility affects tax avoidance. As shown in all columns of panel C, the coefficients of $S M E$ are significantly negative. For example, the coefficient of $S M E$ estimated from the local linear regression with covariates is -0.039 and is significant at the $1 \%$ level. The sharp RDD estimates are approximately the product of the IV estimate and first-stage estimate.

In panels $C$ and $D$ of Table 5, we use an alternative measure of tax avoidance proposed by Desai and Dharmapala (2006). The results are consistent with the estimates obtained using $B T D$ to measure tax avoidance.

\section{Placebo tests}

Our main results depend on the continuity of the density function of the running variable at the real cutoff $(S A L E D I F F=0)$. However, the density function of the running variable may be continuous at many other points. To exclude the possibility that the outcome variable jumps at these points, we use placebo tests to examine the discontinuity estimates of the outcome variable at certain pseudo cutoff points. Table 6 presents the results. For pseudo cutoff points (SALEDIFF $=-0.1,0.15,0.2,-0.25)$, the coefficients estimated using both fuzzy RDD and sharp RDD are neither statistically significant nor robust based on different regression models. This suggests that a discontinuous reduction in tax avoidance will hardly occur unless the firm is truly an SME. 
Table 5 Effects of TRRRCs on corporate tax avoidance

\begin{tabular}{|c|c|c|c|c|c|c|}
\hline & \multicolumn{2}{|l|}{$75 \%$ CCTF } & \multicolumn{2}{|l|}{ CCTF } & \multicolumn{2}{|l|}{$150 \%$ CCTF } \\
\hline & $(1)$ & (2) & (3) & (4) & $(5)$ & $(6)$ \\
\hline \multicolumn{7}{|c|}{ Panel A: 2SLS (dependent variable: BTD) } \\
\hline \multirow[t]{2}{*}{$T R C$} & $-0.318^{* *}$ & $-0.324^{*}$ & $-0.264^{*}$ & $-0.206^{* *}$ & $-0.248^{* * *}$ & $-0.212^{* *}$ \\
\hline & $(0.132)$ & $(0.188)$ & $(0.139)$ & $(0.101)$ & $(0.095)$ & $(0.097)$ \\
\hline Polynomial & Linear & Quadratic & Linear & Quadratic & Linear & Quadratic \\
\hline Covariates & No & Yes & Yes & No & No & Yes \\
\hline Sample size & 1532 & 2921 & 1844 & 4843 & 3718 & 6686 \\
\hline \multicolumn{7}{|c|}{ Panel B: Sharp RDD (dependent variable: BTD) } \\
\hline \multirow[t]{2}{*}{ SME } & $-0.048^{* * *}$ & $-0.048^{* * *}$ & $-0.039 * * *$ & $-0.043^{* * *}$ & $-0.042^{* * *}$ & $-0.040^{* * *}$ \\
\hline & $(0.015)$ & $(0.017)$ & $(0.012)$ & $(0.014)$ & $(0.010)$ & $(0.012)$ \\
\hline Polynomial & Linear & Quadratic & Linear & Quadratic & Linear & Quadratic \\
\hline Covariates & No & Yes & Yes & No & No & Yes \\
\hline Sample size & 1599 & 3079 & 2649 & 4816 & 3858 & 6968 \\
\hline \multicolumn{7}{|c|}{ Panel C: 2SLS (dependent variable:DDBTD) } \\
\hline \multirow[t]{2}{*}{$T R C$} & $-0.257^{* * *}$ & $-0.246^{*}$ & $-0.157^{*}$ & $-0.141^{* *}$ & $-0.162^{* *}$ & $-0.129^{*}$ \\
\hline & $(0.010)$ & $(0.132)$ & $(0.091)$ & $(0.070)$ & $(0.075)$ & $(0.075)$ \\
\hline Polynomial & Linear & Quadratic & Linear & Quadratic & Linear & Quadratic \\
\hline Covariates & No & Yes & Yes & No & No & Yes \\
\hline Sample size & 1532 & 2921 & 2460 & 5794 & 3718 & 6661 \\
\hline \multicolumn{7}{|c|}{ Panel D: Sharp RDD (dependent variable:DDBTD) } \\
\hline \multirow[t]{2}{*}{ SME } & $-0.035^{* * *}$ & $-0.037^{* *}$ & $-0.025^{* *}$ & $-0.031^{* * *}$ & $-0.028^{* * *}$ & $-0.025^{* *}$ \\
\hline & $(0.013)$ & $(0.015)$ & $(0.010)$ & $(0.012)$ & $(0.009)$ & $(0.010)$ \\
\hline Polynomial & Linear & Quadratic & Linear & Quadratic & Linear & Quadratic \\
\hline Covariates & No & Yes & Yes & No & No & Yes \\
\hline Sample size & 1766 & 3079 & 2860 & 5498 & 4271 & 6968 \\
\hline
\end{tabular}

TRC is an indicator variable that is equal to one if the firm's bank loan raise after TRRRCs. SME is an indicator variable that is equal to one if the firm's operation revenue was below the threshold of operation revenue. Columns (1) and (2) are based on $75 \%$ of CCTF bandwidth, Columns (3) and (4) use CCTF bandwidth, and Columns (5) and (6) use sample firms within $150 \%$ of CCTF bandwidth. The discontinuity estimates are based on local linear/quadratic regressions. Standard errors are in the parentheses. ${ }^{*},{ }^{* *}$, and ${ }^{* * *}$ represent statistical significance level at the $1 \%, 5 \%$ and $10 \%$ levels, respectively

\section{Robustness tests}

\section{Parametric analysis}

We use parametric regression to further guarantee the robustness of the baseline results. Following Chava and Roberts (2008) and Zhang (2019), observations falling within the CCTF bandwidth are used to estimate local linear regressions. Both $B T D$ and $D D B T D$ are used for measuring tax avoidance. We control for the lagged SALEDIFF and its interaction term with SME, industry-fixed effect, and year-fixed effect. Considering possible nonlinearity, we also estimate regression models with the quadratic term of the lagged SALEDIFF. Table 7 reports the corresponding estimation results.

Columns (1)-(4) in Table 7 are the results of the regressions without the quadratic term of the lagged SALEDIFF. Regardless of whether firm characteristics are accounted for, the coefficients of $S M E$ are significantly negative, suggesting a reduction in tax avoidance among SMEs after TRRRCs. Controlling for the quadratic term of the lagged SALEDIFF, we find a similar implication. 
Table 6 Effects of TRRRCs on corporate tax avoidance: placebo tests

\begin{tabular}{|c|c|c|c|c|c|c|c|c|}
\hline & \multicolumn{2}{|c|}{ Cutoff $=-0.1$} & \multicolumn{2}{|c|}{ Cutoff $=0.15$} & \multicolumn{2}{|c|}{ Cutoff $=-0.25$} & \multicolumn{2}{|c|}{ Cutoff $=0.2$} \\
\hline & (1) & $(2)$ & (3) & (4) & (5) & (6) & (7) & (8) \\
\hline \multicolumn{9}{|c|}{ Panel A: 2SLS (dependent variable: BTD) } \\
\hline \multirow[t]{2}{*}{$T R C$} & -0.040 & -0.002 & 0.251 & 0.097 & 0.394 & 20.5 & 0.017 & -0.034 \\
\hline & $(0.082)$ & $(0.077)$ & $(0.680)$ & $(0.392)$ & $(0.710)$ & $(66.115)$ & $(0.283)$ & 0.182 \\
\hline Polynomial & Linear & Quadratic & Linear & Quadratic & Linear & Quadratic & Linear & Quadratic \\
\hline Covariates & No & Yes & Yes & No & No & Yes & Yes & No \\
\hline Sample size & 2653 & 4453 & 2463 & 4176 & 3727 & 5197 & 2618 & 4216 \\
\hline \multicolumn{9}{|c|}{ Panel B: Sharp RDD (dependent variable: BTD) } \\
\hline \multirow[t]{2}{*}{ SME } & -0.009 & -0.000 & -0.017 & -0.011 & 0.014 & $0.022^{* *}$ & -0.003 & 0.002 \\
\hline & $(0.009)$ & $(0.012)$ & $(0.012)$ & $(0.015)$ & $(0.009)$ & $(0.011)$ & $(0.012)$ & $(0.015)$ \\
\hline Polynomial & Linear & Quadratic & Linear & Quadratic & Linear & Quadratic & Linear & Quadratic \\
\hline Covariates & No & Yes & Yes & No & No & Yes & Yes & No \\
\hline Sample size & 3575 & 3149 & 2535 & 4414 & 3078 & 4171 & 2673 & 4246 \\
\hline
\end{tabular}

Table 7 Parametric regressions for effects of TRRRCs on corporate tax avoidance

\begin{tabular}{|c|c|c|c|c|c|c|c|c|}
\hline & $\begin{array}{l}(1) \\
\text { BTD }\end{array}$ & $\begin{array}{l}\text { (2) } \\
\text { BTD }\end{array}$ & $\begin{array}{l}\text { (3) } \\
\text { DDBTD }\end{array}$ & $\begin{array}{l}\text { (4) } \\
\text { DDBTD }\end{array}$ & $\begin{array}{l}\text { (5) } \\
\text { BTD }\end{array}$ & $\begin{array}{l}\text { (6) } \\
\text { BTD }\end{array}$ & $\begin{array}{l}(7) \\
\text { DDBTD }\end{array}$ & $\begin{array}{l}\text { (8) } \\
\text { DDBTD }\end{array}$ \\
\hline \multirow[t]{2}{*}{$S M E$} & $-0.041^{* * *}$ & $-0.036^{* * *}$ & $-0.026^{* *}$ & $-0.025^{* *}$ & $-0.029^{* * *}$ & $-0.028^{* * *}$ & $-0.021^{* * *}$ & $-0.023^{* * *}$ \\
\hline & $(0.011)$ & $(0.011)$ & $(0.010)$ & $(0.010)$ & $(0.008)$ & $(0.008)$ & $(0.007)$ & $(0.008)$ \\
\hline \multirow[t]{2}{*}{ SALEDIFF } & 0.007 & -0.000 & -0.006 & -0.011 & -0.010 & -0.009 & -0.018 & -0.015 \\
\hline & $(0.013)$ & $(0.011)$ & $(0.012)$ & $(0.011)$ & $(0.015)$ & $(0.018)$ & $(0.012)$ & $(0.018)$ \\
\hline \multicolumn{2}{|c|}{ SME $\times$ SALEDIFF -0.003} & 0.003 & 0.020 & 0.021 & -0.005 & -0.001 & 0.027 & 0.027 \\
\hline & $(0.022)$ & $(0.020)$ & $(0.021)$ & $(0.019)$ & $(0.029)$ & $(0.035)$ & $(0.022)$ & $(0.034)$ \\
\hline \multirow[t]{2}{*}{ SALEDIFF ${ }^{2}$} & & & & & 0.002 & 0.000 & -0.005 & -0.003 \\
\hline & & & & & $(0.009)$ & $(0.012)$ & $(0.006)$ & $(0.012)$ \\
\hline \multirow[t]{3}{*}{ CFO } & & $0.072^{* * *}$ & & 0.012 & & $0.071^{* * *}$ & & $0.021^{* *}$ \\
\hline & & $(0.013)$ & & $(0.012)$ & & $(0.009)$ & & $(0.009)$ \\
\hline & & -0.017 & & $-0.021^{*}$ & & -0.004 & & -0.006 \\
\hline \multirow[t]{2}{*}{ LEVERAGE } & & $(0.013)$ & & $(0.012)$ & & $(0.009)$ & & $(0.009)$ \\
\hline & & -0.019 & & 0.014 & & -0.029 & & -0.001 \\
\hline \multirow[t]{2}{*}{ INVESTMENT } & & $(0.027)$ & & $(0.025)$ & & $(0.020)$ & & $(0.019)$ \\
\hline & & $0.038^{* *}$ & & $0.083^{* * *}$ & & 0.020 & & $0.071^{* * *}$ \\
\hline \multirow[t]{2}{*}{ FIXED } & & $(0.018)$ & & $(0.016)$ & & $(0.013)$ & & $(0.012)$ \\
\hline & & $0.072^{* * *}$ & & 0.012 & & $0.071^{* * *}$ & & $0.021^{* *}$ \\
\hline \multirow[t]{2}{*}{ Constant } & -0.027 & -0.042 & -0.010 & -0.055 & 0.008 & -0.005 & 0.045 & -0.006 \\
\hline & $(0.071)$ & $(0.070)$ & $(0.063)$ & $(0.063)$ & $(0.034)$ & $(0.038)$ & (0.029) & $(0.035)$ \\
\hline Industry & Yes & Yes & Yes & Yes & Yes & Yes & Yes & Yes \\
\hline Year & Yes & Yes & Yes & Yes & Yes & Yes & Yes & Yes \\
\hline N & 2,212 & 2,402 & 2,244 & 2,445 & 4,832 & 4,228 & 5,816 & 4,193 \\
\hline$R^{2}$ & 0.096 & 0.125 & 0.094 & 0.109 & 0.096 & 0.124 & 0.076 & 0.101 \\
\hline
\end{tabular}

This table presents estimates of parametric regressions using sample firms falling in the bandwidth based on CCTF. BTD and DDBTD are variables to measure tax avoidance. Columns (1)-(4) exclude the quadratic term of SALEDIFF and Columns (5)-(8) include. All regressions control for industry and year fixed effects. Standard errors are in the parentheses. * ,**, and *** represent statistical significance level at the $1 \%, 5 \%$ and $10 \%$ levels, respectively. 
Table 8 Effects of TRRRCs on corporate tax avoidance in 2015

\begin{tabular}{|c|c|c|c|c|c|c|}
\hline & \multicolumn{2}{|l|}{ 75\% CCTF } & \multicolumn{2}{|l|}{ CCTF } & \multicolumn{2}{|l|}{$150 \%$ CCTF } \\
\hline & (1) & (2) & (3) & (4) & (5) & $(6)$ \\
\hline \multicolumn{7}{|c|}{ Panel A: 2SLS (dependent variable: BTD) } \\
\hline \multirow[t]{2}{*}{ TRC } & $-0.201^{*}$ & -0.261 & $-0.252^{*}$ & $-0.203^{*}$ & $-0.215^{* *}$ & $-0.235^{* *}$ \\
\hline & $(0.117)$ & $(0.171)$ & $(0.139)$ & $(0.113)$ & $(0.095)$ & $(0.010)$ \\
\hline Polynomial & Linear & Quadratic & Linear & Quadratic & Linear & Quadratic \\
\hline Covariates & No & Yes & Yes & No & No & Yes \\
\hline Sample size & 1326 & 2516 & 1734 & 3795 & 3182 & 5076 \\
\hline \multicolumn{7}{|c|}{ Panel B: Sharp RDD (dependent variable: BTD) } \\
\hline \multirow[t]{2}{*}{ SME } & $-0.046^{* *}$ & $-0.044^{* *}$ & $-0.039^{* * *}$ & $-0.040^{* *}$ & $-0.041^{* * *}$ & $-0.038^{* * *}$ \\
\hline & $(0.018)$ & $(0.019)$ & $(0.015)$ & $(0.017)$ & $(0.012)$ & $(0.013)$ \\
\hline Polynomial & Linear & Quadratic & Linear & Quadratic & Linear & Quadratic \\
\hline Covariates & No & Yes & Yes & No & No & Yes \\
\hline Sample size & 1190 & 2641 & 1786 & 3810 & 2794 & 5822 \\
\hline
\end{tabular}

TRC is an indicator variable that is equal to one if the firm's bank loan raise after TRRRCs. SME is an indicator variable that is equal to one if the firm's operation revenue was below the threshold of operation revenue. Columns (1) and (2) are based on $75 \%$ of CCTF bandwidth, Columns (3) and (4) use CCTF bandwidth, and Columns (5) and (6) use sample firms within $150 \%$ of CCTF bandwidth. The discontinuity estimates are based on local linear/quadratic regressions. Standard errors are in the parentheses. ${ }^{*}, * *$, and ${ }^{* * *}$ represent statistical significance level at the $1 \%, 5 \%$ and $10 \%$ levels, respectively

\section{Effects of TRRRCs on corporate tax avoidance in 2015}

Since the TRRRC policy was enacted in the second half of 2014, firms may have managed their sales to cater to this policy over the relatively long term. This potential manipulation would lead to the identification bias of treated and controlled firms in the future. Thus, we rerun the estimation based solely on observations in 2015 (the next financial year after the release of the TRRRC policy). This test also helps to eliminate the potential effects of other policies implemented during the study period. Table 8 presents the results.

The results in Table 8 suggest that in the first year of the TRRRC, SMEs engaged in less tax avoidance.

\section{Effect of macroeconomic and monetary policies}

To eliminate the effects of other macroeconomic and monetary policies, we include the growth of M2 to measure the change in money supply policy and the growth of the GDP to measure the change in the local economic environment and national macroeconomic policy. Table 9 presents the results.

In Table 9, the estimates are significantly negative, as in the previous results. We propose that the estimates in Table 9 indicate that TRRRCs have significantly increased SMEs' access to finance and reduced their tax avoidance.

\section{Mechanisms}

The size and debt level of a firm can reflect whether it is subject to financing constraints (Hu and Schiantarelli 1998; Cleary 1999; Almeida et al. 2004; Krishnan et al. 2015). To show that Chinese SMEs are more likely to be financing constrained, we 
Table 9 Effect of macroeconomic and monetary policies

\begin{tabular}{|c|c|c|c|c|}
\hline & \multicolumn{2}{|l|}{ BTD } & \multicolumn{2}{|l|}{ DDBTD } \\
\hline & (1) & $(2)$ & (3) & (4) \\
\hline \multicolumn{5}{|l|}{ Panel A: 2SLS } \\
\hline \multirow[t]{2}{*}{$T R C$} & $-0.270^{*}$ & $-0.220^{*}$ & $-0.173^{*}$ & $-0.159^{*}$ \\
\hline & $(0.138)$ & $(0.119)$ & $(0.098)$ & $(0.085)$ \\
\hline Polynomial & Linear & Quadratic & Linear & Quadratic \\
\hline Covariates & Yes & Yes & Yes & Yes \\
\hline Sample size & 2214 & 4667 & 2440 & 4919 \\
\hline \multicolumn{5}{|c|}{ Panel B: Sharp RDD } \\
\hline \multirow[t]{2}{*}{$S M E$} & $-0.041^{* * *}$ & $-0.041^{* * *}$ & $-0.027^{* * *}$ & $-0.027^{* *}$ \\
\hline & $(0.012)$ & $(0.014)$ & $(0.010)$ & $(0.012)$ \\
\hline Polynomial & Linear & Quadratic & Linear & Quadratic \\
\hline Covariates & Yes & Yes & Yes & Yes \\
\hline Sample size & 2421 & 4981 & 2638 & 5135 \\
\hline
\end{tabular}

$\overline{T R C}$ is an indicator variable that is equal to one if the firm's bank loan raise after TRRRCs. SME is an indicator variable that is equal to one if the firm's operation revenue was below the threshold of operation revenue. BTD and DDBTD are variables to measure tax avoidance. The discontinuity estimates are based on local linear/quadratic regressions. Standard errors are in the parentheses. ${ }^{*},{ }^{* *}$, and ${ }^{* * *}$ represent statistical significance level at the $1 \%, 5 \%$ and $10 \%$ levels, respectively

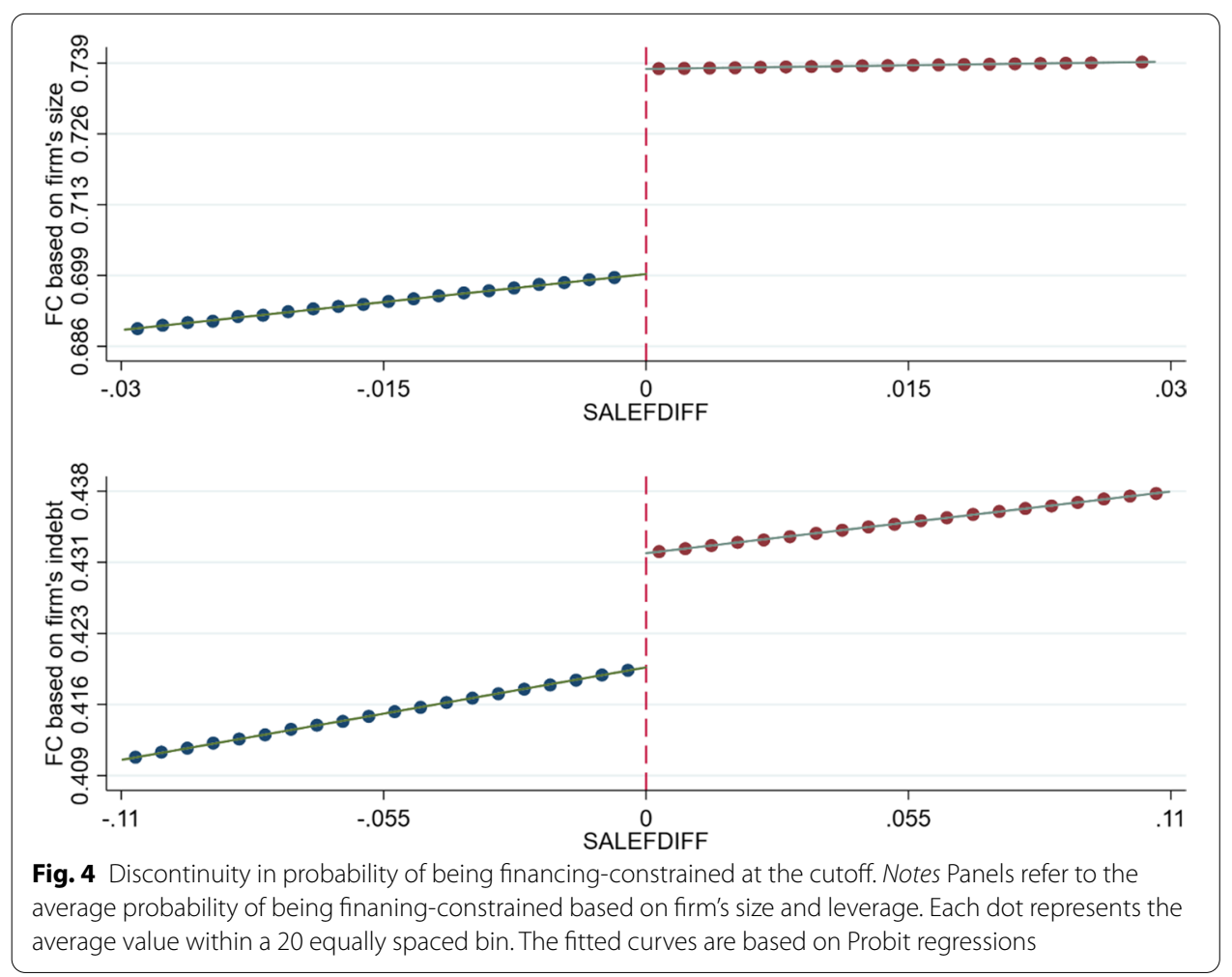

follow Hubbard (1998) to divide our sample by size and leverage tertiles. We define a dummy variable $F C$ to indicate firms' financing status. For firms with a size (leverage) below the first tertile, we assign $F C$ to 1 , suggesting that the firm faces financing 

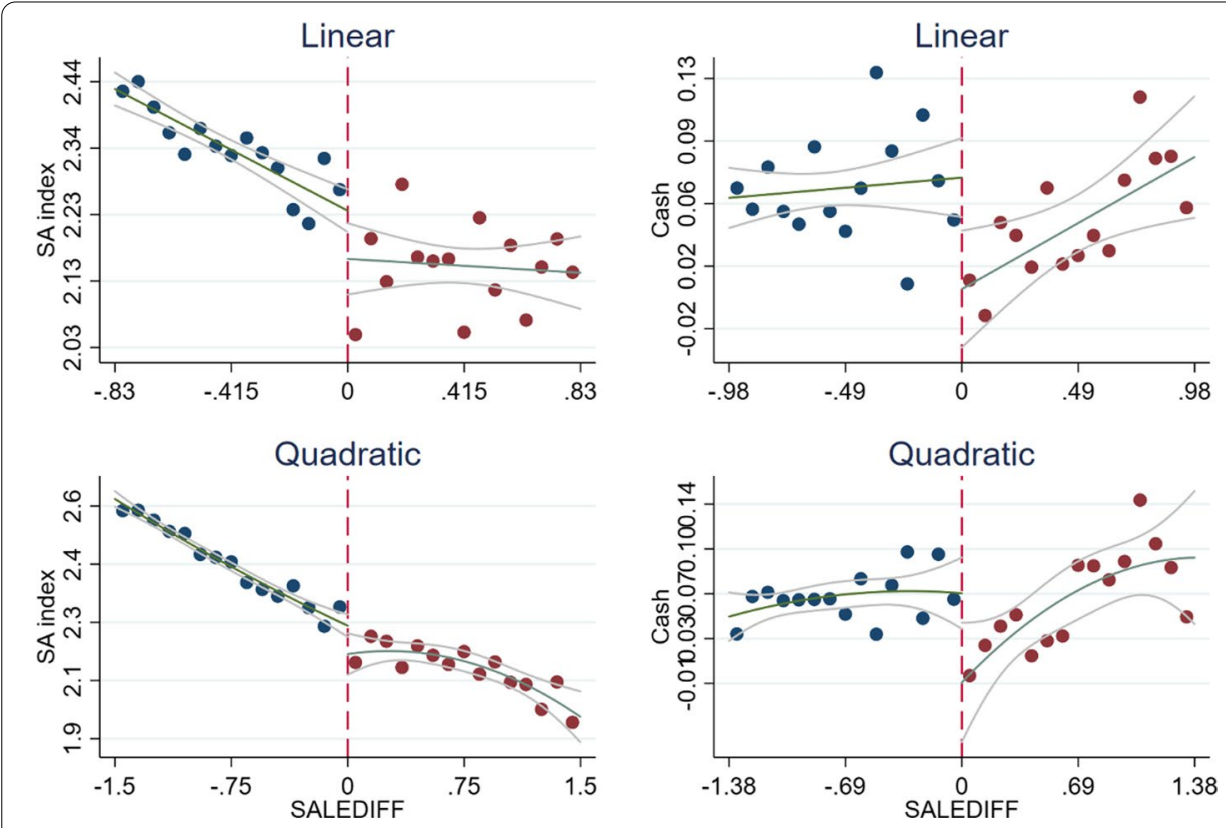

Fig. 5 Discontinuity in financing constraint and cash dependence at the cutoff. Notes Panels refer to the average SA index and cash dependence (from left to right). Each dot represents the average value within a 15 equally spaced bin. The fitted curves are based on linear regressions (top graphs) and quadratic regressions (bottom graphs), separately, with a 95\% confidence interval around the predicted value

constraints. Figure 4 plots the average probability of being financing constrained. ${ }^{6}$ Based on firm size (leverage), Fig. 4 intuitively shows that SMEs are $4 \%(1 \%)$ more likely to be financing constrained than other firms.

Given the financial constraints faced by SMEs, the difficulty of obtaining external financing causes them to rely on internal financing, which has led to corporate tax avoidance. We expect that if TRRRCs ease the financial constraints of SMEs by improving loan availability, SMEs' incentives for tax avoidance will decrease. We use the SA index (Hadlock and Pierce 2010) to measure corporate financial constraints. The higher the SA index, the more severe the financial constraints. We first provide graphical evidence to show the discontinuity of financial constraints at the cutoff. The left two graphs in Fig. 5 present the RDD plots of financial constraints based on linear and quadratic fitted functions. On the left side of Fig. 5, the financial constraints of firms toward the right of the cutoff are significantly lower than those toward the left of the cutoff, suggesting that TRRRCs ease SMEs' financing constraints. Columns (1) and (2) of Table 10 report the formal estimate results. Panels A and B present the fuzzy RDD regression results. In column (1), the coefficient of TRC in the IV estimation is -0.479 and significant at the $10 \%$ level, suggesting that the financing constraints of SMEs decrease after TRRRCs improve firms' loan availability. The sharp RDD estimation in panel $\mathrm{C}$ shows that the coefficient of $S M E$ is -0.052 , roughly equaling $-0.479 \times 0.134$ and significant at the $1 \%$ level. Overall, the results demonstrate the effectiveness of TRRRCs for easing the financial constraints of SMEs.

\footnotetext{
${ }^{6}$ We used a probit model to evaluate the probability of firms' financial constraints.
} 
Table 10 Effects of TRRRCs on financing constrains and cash dependence

\begin{tabular}{|c|c|c|c|c|}
\hline & \multicolumn{2}{|l|}{ SA } & \multicolumn{2}{|l|}{ CASH } \\
\hline & (1) & (2) & (3) & (4) \\
\hline \multicolumn{5}{|c|}{ Panel A: 2SLS (dependent variable: SA or CASH) } \\
\hline \multirow[t]{2}{*}{ TRC } & $-0.479^{*}$ & $-0.782^{* *}$ & $-0.426^{*}$ & $-0.345^{*}$ \\
\hline & $(0.282)$ & $(0.400)$ & $(0.246)$ & $(0.200)$ \\
\hline Polynomial & Linear & Quadratic & Linear & Quadratic \\
\hline Covariates & Yes & No & Yes & No \\
\hline Sample size & 2394 & 4680 & 2141 & 4562 \\
\hline \multicolumn{5}{|c|}{ Panel B: Sharp RDD (dependent variable: SA or CASH) } \\
\hline \multirow[t]{2}{*}{$S M E$} & $-0.052^{* * *}$ & $-0.117^{* * *}$ & $-0.070^{* * *}$ & $-0.059^{* *}$ \\
\hline & $(0.012)$ & $(0.044)$ & $(0.023)$ & $(0.029)$ \\
\hline Polynomial & Linear & Quadratic & Linear & Quadratic \\
\hline Covariates & Yes & No & Yes & No \\
\hline Sample size & 4785 & 5190 & 2978 & 4588 \\
\hline
\end{tabular}

Panel A presents fuzzy RDD results based on an IV framework. Panel B represents sharp RDD results. The dependent variable $S A$ measures Financial constraint and CASH measures cash dependence. TRC is an indicator variable that is equal to one if the firm's bank loan raise after TRRRCs. SME is an indicator variable that is equal to one if the firm's operation revenue was below the threshold of operation revenue. The discontinuity estimates are based on local linear/quadratic regressions. Standard errors are in the parentheses. ${ }^{*}, * *$, and ${ }^{* * *}$ represent statistical significance level at the $1 \%, 5 \%$ and $10 \%$ levels, respectively

Given the difficulty of obtaining bank loans and the need to meet production demands, SMEs are highly dependent on cash. The direct effect of tax avoidance is to improve the internal cash-holding level of a firm and ensure normal operations. TRRRCs require banks to inject the released funds into weak areas of the national economy, such as SMEs, which reduces the difficulty firms face in obtaining bank loans. The substitution effect of loans on cash can ease the dependence of SMEs on cash, which further weakens their tax-avoidance motivation. We use the ratio of the net increase in cash and cash equivalents to total assets $(C A S H)$ to measure a firm's dependence on cash. This is because the larger the value of $C A S H$, the higher the growth of the firm's cash level, and the greater the demand for cash. Using RDD, we analyze the effect of TRRRCs on firms' cash dependence. We first present the RDD plots in Fig. 5. The right two graphs in Fig. 5 show discontinuity in cash dependence at the threshold and depict a reduction in SMEs' cash dependence after TRRRCs. Columns (3) and (4) in Table 10 report the estimation results. The fuzzy RDD estimates in panels A and B and the sharp RDD estimates in panel C show that TRRRCs significantly reduce SMEs' cash dependence by increasing firms' access to finance.

\section{Further analysis}

\section{Cross-sectional analysis of corporate tax avoidance}

We have argued that SMEs' reduction in tax avoidance is attributable to the easing of financial constraints and cash dependence after TRRRCs increase loan availability. However, as mentioned above, loan availability for SMEs is only likely to rise after TRRRCs. For what types of firms is loan availability more likely to increase? We use cross-sectional tests in this section to elaborate some further implications of the main results. 
Table 11 Cross-sectional tests based on market power and ETCS

\begin{tabular}{|c|c|c|c|c|c|c|}
\hline & \multicolumn{3}{|c|}{ Higher market power } & \multicolumn{3}{|c|}{ Lower market power } \\
\hline & $(1)$ & (2) & (3) & $(4)$ & (5) & (6) \\
\hline & BTD & $S A$ & CASH & BTD & $S A$ & CASH \\
\hline \multicolumn{7}{|c|}{ Panel A: Cross-sectional tests based on market power } \\
\hline \multicolumn{7}{|c|}{ Results based on 2SLS } \\
\hline \multirow[t]{2}{*}{$T R C$} & $0.089^{\prime}$ & 0.374 & -0.876 & $-0.335^{* *}$ & $-0.801^{* *}$ & $-0.420^{* *}$ \\
\hline & $(0.112)$ & $(0.928)$ & $(1.355)$ & $(0.144)$ & $(0.317)$ & $(0.214)$ \\
\hline Sample size & 1224 & 1054 & 865 & 1240 & 1860 & 2564 \\
\hline \multicolumn{7}{|c|}{ Results based on Sharp RDD } \\
\hline \multirow[t]{2}{*}{ SME } & 0.010 & 0.040 & -0.081 & $-0.070^{* * *}$ & $-0.180^{* * *}$ & $-0.070^{* *}$ \\
\hline & $(0.009)$ & $(0.057)$ & $(0.049)$ & $(0.020)^{`}$ & $(0.045)$ & $(0.030)$ \\
\hline \multirow[t]{4}{*}{ Sample size } & 1264 & 1249 & 776 & 1116 & 1331 & 2582 \\
\hline & \multicolumn{3}{|l|}{ Higher ETCs } & \multicolumn{3}{|l|}{ Lower ETCS } \\
\hline & (1) & $(2)$ & (3) & (4) & (5) & (6) \\
\hline & BTD & $S A$ & CASH & BTD & $S A$ & CASH \\
\hline \multicolumn{7}{|c|}{ Panel B: Cross-sectional tests based on ETCS } \\
\hline \multicolumn{7}{|c|}{ Results based on 2SLS } \\
\hline \multirow[t]{2}{*}{$T R C$} & $-0.262^{*}$ & $-0.668^{*}$ & $-0.538^{* *}$ & -0.165 & -0.331 & -0.433 \\
\hline & $(0.148)$ & $(0.394)$ & $(0.633)$ & $(0.125)$ & $(0.633)$ & $(0.380)$ \\
\hline Sample size & 1586 & 1976 & 2460 & 625 & 828 & 593 \\
\hline \multicolumn{7}{|c|}{$\begin{array}{l}\text { Results based on } \\
\text { Sharp RDD }\end{array}$} \\
\hline \multirow[t]{2}{*}{$S M E$} & $-0.040^{* * *}$ & $-0.113^{* *}$ & $-0.083^{* * *}$ & -0.027 & -0.046 & -0.070 \\
\hline & $(0.015)$ & $(0.045)$ & $(0.031)$ & $(0.017)$ & $(0.065)$ & $(0.047)$ \\
\hline Sample size & 1712 & 1912 & 2328 & 571 & 819 & 668 \\
\hline \multicolumn{7}{|c|}{$\begin{array}{l}\text { This table reports RDD results of cross-sectional tests for tax avoidance, financial constraints and cash dependence. Panel } \\
\text { A presents cross-sectional tests based on market power. Panel B represents cross-sectional tests based on ETCs. The } \\
\text { dependent variables are tax avoidance (BTD), financial constraints (SA) and cash dependence (CASH). Market power is } \\
\text { measured as the gross profit margin. ETCs is calculated as entertainment and travel costs scaled by operation revenue. We } \\
\text { divide the full sample into two groups respectively based on the medians of market power and ETCs to exercise the cross- } \\
\text { sectional tests. TRC is an indicator variable that is equal to one if the firm's bank loan raise after TRRRCs. SME is an indicator } \\
\text { variable that is equal to one if the firm's operation revenue was below the threshold of operation revenue. The discontinuity } \\
\text { estimates are based on local linear regressions. Standard errors are in the parentheses. *, **, and *** represent statistical } \\
\text { significance level at the } 1 \%, 5 \% \text { and } 10 \% \text { levels, respectively }\end{array}$} \\
\hline
\end{tabular}

First, we examine whether TRRRCs have inclusive effects. TRRRCs aim to support the development and growth of weak sectors. On the one hand, SMEs with weak market power face more serious financial constraints, and TRRRCs can be described as "delivering carbon in the snow." On the other hand, due to weak market power, granting credit to these firms requires banks to further strengthen their monitoring, resulting in increased tax-avoidance risks for the firms. Therefore, for firms with weak market power, the negative effect of TRRRCs on their tax avoidance is more prominent. We use the gross profit margin to measure market power. The gross profit margin can be used as a proxy for relative price markup and can measure the market power of a firm (Lerner 1934). We divide the full sample into two groups based on whether the gross profit margin is greater than the median. We separately examine the effect of TRRRCs on tax avoidance for firms in the higher market power subsample and the lower market power subsample. 
Columns (1) and (4) in panel A of Table 11 report the estimated results. The IV estimation in panel A shows that increased loan availability more likely reduces tax avoidance for SMEs with lower market power. The sharp RDD results suggest the same. These results provide evidence for the inclusive effect of TRRRCs.

SMEs generally have difficulties with financing and are eager to obtain bank loans. Given the small scale and high operating risks of SMEs, their relationships with the government and with banks are usually weak. To obtain financial support, SMEs may actively seek to establish relationships with the government and banks. Chen et al. (2013) found that bribery is conducive to establishing relationships with governments and banks, which in turn facilitates corporate access to bank credit. Following Cai et al. (2011) and Chen et al. (2013), we use entertainment and travel costs (ETCs) as a proxy for corporate bribery. As above, with reference to the median of ETCs, the entire sample is divided into two groups. We then examine the effect of TRRRCs on firms' tax avoidance for each subsample. Columns (1) and (4) in panel B of Table 11 report the results. The fuzzy RDD results suggest that SMEs with higher ETCs gain easier access to loans after TRRRCs, leading to a reduction in tax avoidance. The sharp RDD estimation in panel B-2 further confirms this result. This result may be attributable to the following. SMEs with higher ETCs are more politically connected and enjoy preferential lending as well as more credit resources released by TRRRCs. Their financing conditions have improved, and their need to avoid taxes has been reduced. Meanwhile, these firms might have engaged in excessive tax avoidance (Shen et al. 2019) before TRRRCs. Thus, more access to bank loans helps stimulate them to reduce the risk of tax avoidance.

\section{Cross-sectional analysis of mechanisms}

The empirical results of the mechanism test show that, after TRRRCs, loan availability for SMEs is likely to improve, thus alleviating financial constraints and cash dependence and ultimately reducing tax avoidance. To ensure that this mechanism is convincing, based on the same firm characteristics as above (i.e., market power and ETCs), we perform a cross-sectional test of the mechanism. Table 11 reports the RDD results.

The results in columns (2)-(3) and (5)-(6) in Table 11 suggest that firms with lower market power and higher ETCs are more affected by TRRRCs. For these firms, the coefficients of TRC based on fuzzy RDD and the coefficients of $S M E$ based on sharp RDD are significantly negative for financial constraints and cash dependence. These results show that TRRRCs are more conducive to easing financial constraints and cash dependence for firms with weaker market power and more bribery, which is consistent with the heterogeneous effect of TRRRCs on tax avoidance.

\section{Effect of TRRRCs on tax payments}

A possible implication of the reduction in SMEs' tax avoidance is that the taxation of SMEs has improved. In this section, we examine whether SMEs' tax payments increase after TRRRCs. The outcome variable is TAX_PAYMENT, which is equal to tax payments divided by operational revenues. Tax payments mainly include taxes and fees, such as value-added tax, consumption tax, customs duty, income tax, education surcharge, and mineral resource compensation fee. Table 12 presents the RDD results. The coefficients of $T R C$ based on fuzzy RDD and the coefficients of $S M E$ based on sharp RDD are 
Table 12 The effect of TRRRCs on tax payments

\begin{tabular}{lllll}
\hline & $(1)$ & $(2)$ & $(3)$ & $(4)$ \\
\hline Panel A: 2SLS (dependent variable:TAX_PAYMENT) & & & \\
TRC & $0.096^{*}$ & $0.097^{*}$ & $0.092^{* *}$ & $0.090^{*}$ \\
Polynomial & $(0.051)$ & $(0.055)$ & $(0.046)$ & $(0.054)$ \\
Covariates & Linear & Linear & Quadratic & Quadratic \\
Sample size & No & Yes & No & Yes \\
Panel B: Sharp RDD (dependent variable:TAX_PAYMENT) & 2200 & 4936 & 3951 \\
SME & 2201 & $0.019^{* * *}$ & & \\
& $0.020^{* * *}$ & $(0.005)$ & $0.017^{* *}$ & $0.016^{* *}$ \\
Polynomial & $(0.005)$ & Linear & $(0.007)$ & $(0.007)$ \\
Covariates & Linear & Yes & Quadratic & Quadratic \\
Sample size & No & 3365 & No & Yes \\
\hline
\end{tabular}

$T R C$ is an indicator variable that is equal to one if the firm's bank loan raise after TRRRCs. SME is an indicator variable that is equal to one if the firm's operation revenue was below the threshold of operation revenue. TAX_PAYMENT measures tax payments. The discontinuity estimates are based on local linear/quadratic regressions. Standard errors are in the parentheses. * **, and *** represent statistical significance level at the $1 \%, 5 \%$ and $10 \%$ levels, respectively

significantly positive, indicating that the tax payment status of SMEs has improved after TRRRCs.

\section{Conclusions}

Considering that SMEs face financing difficulties, we use financial data of companies on the NEEQ and adopt RD to explore the effect of TRRRCs on corporate tax avoidance. The empirical results show that TRRRCs have a significant negative effect on tax avoidance for SMEs. Because of easier access to financing after TRRRCs, SMEs' financial constraints and dependence on cash decrease, consequently leading to a reduction in tax avoidance. Further analysis shows that the tax avoidance of SMEs with weaker market power and higher ETCs is more negatively affected by TRRRCs, revealing the inclusive effect of TRRRCs and the importance of bribery in the allocation of bank loans in China.

This study contributes to the growing body of research on the effect of access to financing on corporate tax avoidance, especially among SMEs. Moreover, this study helps to clarify the mechanisms that underlie the real effects of relaxed monetary policy on corporate behaviors, such as tax avoidance. From a policy perspective, the government faces a trade-off between the effect of bribery on greasing the wheels of bank lending and curbing corporate tax avoidance.

Acknowledgements

We thank Shasha Liu, Rui Shen, Wei Yang, Xueyong Zhang, Haijian Zeng, and seminar participants at Huazhong University of Science and Technology, Guangxi University, Shandong University, and Zhongnan University of Economics and Law for helpful suggestions. All errors are our own.

\section{Authors' contributions}

XK (first) designed the research, discussed the results and wrote the revised version of this article. DS (second author) applied methodology and empirical results. HL (corresponding author) designed the research, discussed the results, and wrote the article. DK (fourth author) carried out the idea and wrote the article. All authors read and approved the final manuscript.

\section{Funding}

Funding was provided by National Natural Science Foundation of China (Grant No. 71772178).

Availability of data and materials

Data are available CSMAR database (http://www.gtarsc.com). 


\section{Declarations}

Competing interests

The authors declare that they have no competing interests.

\section{Author details}

${ }^{1}$ School of Economics and Management, Dongguan University of Technology, Dongguan, China. ${ }^{2}$ Department of Finance, Qingdao University, Qingdao, China. ${ }^{3}$ School of Finance, Zhongnan University of Economics and Law, Wuhan, China. ${ }^{4}$ School of Economics, Huazhong University of Science and Technology, Wuhan, China.

Received: 28 April 2020 Accepted: 9 March 2021

Published online: 15 March 2021

\section{References}

Allen F, Qian J, Qian M (2005) Law, finance, and economic growth in China. J Financ Econ 77:57-116

Almeida H, Campello M, Weisbach MS (2004) The cash flow sensitivity of cash. J Finance 59:1777-1804

Angrist JD, Lavy V (1999) Using Maimonides' rule to estimate the effect of class size on scholastic achievement. Q J Econ 114:533-575

Bach L (2014) Are small businesses worthy of financial aid? Evidence from a French targeted credit program. Rev Finance 18:877-919

Banerjee AV, Duflo E (2014) Do firms want to borrow more? Testing credit constraints using a directed lending program. Rev Econ Stud 81:572-607

BeckT, Demirguc-Kunt A (2006) Small and medium-size enterprises: access to finance as a growth constraint. J Bank Finance 30:2931-2943

Berger AN, Udell GF (2006) A more complete conceptual framework for SME finance. J Bank Finance 30:2945-2966 Bradley D, Kim I, Tian X (2016) Do unions affect innovation? Manag Sci 63:2251-2271

Brown JR, Fazzari SM, Petersen BC (2009) Financing innovation and growth: cash flow, external equity, and the 1990s R\&D boom. J Finance 64:151-185. https://doi.org/10.1111/j.1540-6261.2008.01431.x

Cai H, Fang H, Xu LC (2011) Eat, drink, firms, government: an investigation of corruption from the entertainment and travel costs of Chinese firms. J Law Econ 54:55-78

Cai J, Chen Y, Wang X (2018) The impact of corporate taxes on firm innovation: evidence from the corporate tax collection reform in China, NBER Working paper. https://www.nber.org/papers/w25146

Calonico S, Cattaneo MD, Farrell MH, Titiunik R (2019) Regression discontinuity designs using covariates. Rev Econ Stat 101:442-451

Calonico S, Cattaneo MD, Titiunik R (2014) Robust nonparametric confidence intervals for regression-discontinuity designs. Econometrica 82:2295-2326

Cao S, Leung D (2019) Credit constraints and productivity of SMEs: evidence from Canada. Econ Model 88:163-180

Chan KH, Lin KZ, Mo PL (2010) Will a departure from tax-based accounting encourage tax noncompliance? Archival evidence from a transition economy. J Account Econ 50:58-73

Chang C, Liu Z, Spiegel MM, Zhang J (2019) Reserve requirements and optimal Chinese stabilization policy. J Monet Econ 103:33-51

Chava S, Roberts MR (2008) How does financing impact investment? The role of debt covenants. J Finance 63:2085-2121

Chemmanur TJ, Tian X (2018) Do antitakeover provisions spur corporate innovation? A regression discontinuity analysis. J Financ Quant Anal 53:1163-1194

Chen S, Chen X, Cheng Q, Shevlin T (2010) Are family firms more tax aggressive than non-family firms? J Financ Econ 95:41-61

Chen Y, Liu M, Su J (2013) Greasing the wheels of bank lending: evidence from private firms in China. J Bank Finance $37: 2533-2545$

Cleary S (1999) The relationship between firm investment and financial status. J Finance 54:673-692

DeAngelo H, Masulis RW (1980) Optimal capital structure under corporate and personal taxation. J Financ Econ 8:3-29

Denis DJ, Sibilkov V (2009) Financial constraints, investment, and the value of cash holdings. Rev Financ Stud 23:247-269

Desai MA, Dharmapala D (2006) Corporate tax avoidance and high-powered incentives. J Financ Econ 79:145-179

Dyreng SD, Hanlon M, Maydew EL (2008) Long-run corporate tax avoidance. Account Rev 83:61-82

Edwards A, Schwab C, Shevlin T (2016) Financial constraints and cash tax savings. Account Rev 91:859-881

Faulkender M, Wang R (2006) Corporate financial policy and the value of cash. J Finance 61:1957-1990

Francis BB, Ren N, Wu Q (2017) Banking deregulation and corporate tax avoidance. China J Account Res 10:87-104

Goh BW, Lee J, Lim CY, Shevlin T (2016) The effect of corporate tax avoidance on the cost of equity. Account Rev 91:1647-1670

Graham JR, Tucker AL (2006) Tax shelters and corporate debt policy. J Financ Econ 81:563-594

Hadlock CJ, Pierce JR (2010) New evidence on measuring financial constraints: Moving beyond the KZ index. Rev Financ Stud 23:1909-1940

Hahn J, Todd P, Van der Klaauw W (2001) Identification and estimation of treatment effects with a regression-discontinuity design. Econometrica 69:201-209

Hasan I, Hoi CKS, Wu Q, Zhang H (2014) Beauty is in the eye of the beholder: the effect of corporate tax avoidance on the cost of bank loans. J Financ Econ 113:109-130

Hou X, Li S (2019) The price of official-business collusion: evidence from the stock market reaction to "Hunting the Tigers" in China. China Finance Rev Int 10:52-74

Hu X, Schiantarelli F (1998) Investment and capital market imperfections: a switching regression approach using US firm panel data. Rev Econ Stat 80:466-479 
Hu Y, Xu M (2019) China's anti-corruption campaign, political connections and private firms' debt financing. China Finance Rev Int 9:521-553

Hubbard RG (1998) Capital-market imperfections and investment. J Econ Lit 36:193-225

Imbens G, Kalyanaraman K (2012) Optimal bandwidth choice for the regression discontinuity estimator. Rev Econ Stud 79:933-959

Imbens GW, Lemieux T (2008) Regression discontinuity designs: a guide to practice. J Econ 142:615-635

Jia J, Shao L, Sun Z, Zhao F (2020) Corporate cash savings and discretionary accruals. China Finance Rev Int ahead-of-print

Kou G, Peng Y, Wang G (2014) Evaluation of clustering algorithms for financial risk analysis using MCDM methods. Inf Sci 275:1-12

Kou G, Xu Y, Peng Y, Shen F, Chen Y, Chang K, Kou S (2020) Bankruptcy prediction for SMEs using transactional data and two-stage multiobjective feature selection. Decis Support Syst 140:113429

Krishnan K, Nandy DK, Puri M (2015) Does financing spur small business productivity? Evidence from a natural experiment. Rev Financ Stud 28:1768-1809

Lanis R, Richardson G, Govendir B, Pazmandy G (2020) The effect of board of directors' expertise and tax avoidance on corporate debt. Account Finance. https://doi.org/10.1111/acfi.12738

Law KK, Mills LF (2015) Taxes and financial constraints: evidence from linguistic cues. J Account Res 53:777-819

Lee DS, Lemieux T (2010) Regression discontinuity designs in economics. J Econ Lit 48:281-355

Lerner AP (1934) The concept of monopoly and the measurement of monopoly power. Rev Econ Stud 1:157-175

Lin C, He L, Yang G (2020) Targeted monetary policy and financing constraints of Chinese small businesses. Small Bus Econ 1-18

Luo J, Ni X, Tian GG (2020) Short selling and corporate tax avoidance: insights from a financial constraint view. Pac-Basin Finance J 61:101323

McCrary J (2008) Manipulation of the running variable in the regression discontinuity design: a density test. J Econ 142:698-714

Meng L (2013) Evaluating China's poverty alleviation program: a regression discontinuity approach. J Public Econ 101:1-11

Pan Y, Singhal S (2019) Agricultural extension, intra-household allocation and malaria. J Dev Econ 139:157-170

Rice T, Strahan PE (2010) Does credit competition affect small-firm finance? J Finance 65:861-889

Richardson G, Lanis R, Taylor G (2015) Financial distress, outside directors and corporate tax aggressiveness spanning the global financial crisis: an empirical analysis. J Bank Finance 52:112-129

Shen Y, Gao D, Bu D, Yan L, Chen P (2019) CEO hometown ties and tax avoidance-evidence from China's listed firms. Account Finance 58:1549-1580

Van der Klaauw W (2002) Estimating the effect of financial aid offers on college enrollment: a regression-discontinuity approach. Int Econ Rev 43:1249-1287

Wu L, Xu L (2020) Venture capital certification of small and medium-sized enterprises towards banks: evidence from China. Account Finance 60:1601-1633

Xiong F, Zheng Y, An Z, Xu S (2020) Does internal information quality impact corporate cash holdings? Evidence from China. Account Finance. https://onlinelibrary.wiley.com/doi/full/10.1111/acfi.12657

Zhang J, Deng X (2020) Interest rate liberalization and bank liquidity creation: evidence from China. China Finance Rev Int 10:377

Zhang Z (2019) Bank interventions and trade credit: evidence from debt covenant violations. J Financ Quant Anal 54:2179-2207

\section{Publisher's Note}

Springer Nature remains neutral with regard to jurisdictional claims in published maps and institutional affiliations.

\section{Submit your manuscript to a SpringerOpen ${ }^{\circ}$ journal and benefit from:}

- Convenient online submission

- Rigorous peer review

- Open access: articles freely available online

- High visibility within the field

- Retaining the copyright to your article

Submit your next manuscript at $\boldsymbol{\nabla}$ springeropen.com 